\title{
A GESTÃO AMBIENTAL DOS MUNICÍPIOS PARAENSES: GASTOS PÚBLICOS, DESCENTRALIZAÇÃO E SUSTENTABILIDADE ${ }^{1,2}$
}

\author{
Alex Santiago Nina ${ }^{3}$ \\ Oriana Trindade de Almeida ${ }^{4}$ \\ Ivonês Damasceno Lobo ${ }^{5}$
}

\begin{abstract}
Desde os anos 1980, a gestão ambiental brasileira passou por um processo de descentralização e aumento das atribuições municipais, o que também vem ocorrendo no estado do Pará. Este trabalho visa avaliar a evolução histórica e o empenho financeiro dos gastos públicos ambientais dos municípios paraenses para responder ao seguinte questionamento: a descentralização da gestão municipal paraense vem sendo acompanhada de proporcional aumento no empenho das despesas ambientais? A metodologia consistiu na análise das despesas ambientais dos municípios paraenses, sua transparência e tendência de crescimento, além de uma focalização em grupos definidos pelo Programa Municípios Verdes (PMV). A hipótese levantada foi de que os municípios com melhor estrutura apresentaram melhor empenho da gestão financeira ambiental. Os resultados constataram a insuficiência e a baixa transparência, com agravamento em anos eleitorais, das despesas ambientais municipais, embora com tendência de crescimento. De onze municípios, a hipótese de pesquisa foi confirmada para apenas dois, Marabá e Paragominas.
\end{abstract}

Palavras-chave: gastos públicos municipais; gestão ambiental; estado do Pará; descentralização; empenho financeiro.

\section{THE ENVIRONMENTAL MANAGEMENT OF THE MUNICIPALITIES OF PARÁ STATE: PUBLIC EXPENDITURE, DECENTRALIZATION AND SUSTAINABILITY}

Since the 1980s, Brazilian environmental management has undergone a process of decentralization and increased municipal attributions, which have also been occurring in the State of Pará. This work aims to evaluate the historical evolution and financial commitment of public environmental expenditures of the municipalities of Pará to respond to the following question: does the decentralization of municipal management in Pará have been accompanied by a proportional increase in the commitment of environmental expenses? The methodology consisted of the analysis of the environmental expenses of the municipalities of Pará, its transparency and tendency of growth, besides a focus in groups defined by the Green Municipalities Program. The hypothesis raised was that the municipalities with better structure presented a better commitment of the environmental financial management. The results verified the insufficiency and low transparency, with aggravation in electoral years, of the municipal environmental expenses, although with a tendency of growth. From 11 municipalities, the research hypothesis was confirmed only for Marabá and Paragominas.

Keywords: municipalities publics spends; environmental management; Pará State; decentralization; financial commitment.

1. DOI: http://dx.doi.org/10.38116/ppp54art03

2. Os autores agradecem ao Ministério da Ciência, Tecnologia, Inovações e Comunicações (MCTIC), ao Conselho Nacional de Desenvolvimento Científico e Tecnológico (CNPq), à Agência Nacional de Águas (ẢNA) e ao Programa Pró-Amazônia, da Coordenação de Aperfeiçoamento de Pessoal de Nível Superior (Capes), pelo apoio a esta pesquisa.

3. Docente na Universidade do Estado do Amapá (Ueap) e na Universidade Federal do Amapá (Unifap). E-mail: $<$ alex.0591@hotmail.com>.

4. Docente na Universidade Federal do Pará (Ufpa).E-mail: <oriana@ufpa.br>.

5. Pós-graduanda em Direito Ambiental na Faculdade Educacional da Lapa (Fael).E-mail: <ivoneslobo@yahoo.com>. 


\section{LA GESTIÓN AMBIENTAL DE LOS MUNICIPIOS PARAENSES: GASTOS PUBLICOS, DESCENTRALIZACIÓN Y SOSTENIBILIDAD}

Desde la década de 1980, la gestión ambiental brasileña pasó por un proceso de descentralización y aumento de las atribuciones municipales, lo que también viene ocurriendo en el Estado de Pará. Este trabajo busca evaluar la evolución histórica y el compromiso financiero de los gastos públicos ambientales de los municipios paraenses para responder al siguiente cuestionamiento: ¿la descentralización de la gestión municipal paraense viene acompañada de proporcional aumento en el compromiso de los gastos ambientales? La metodología consistió en el análisis de los gastos ambientales de los municipios paraenses, su transparencia y tendencia de crecimiento, además de una focalización en grupos definidos por el Programa Municipios Verdes. La hipótesis planteada fue que los municipios con mejor estructura presentaron un mejor compromiso de la gestión financiera ambiental. Los resultados constataron la insuficiencia y baja transparencia, con agravamiento en años electorales, de los gastos ambientales municipales, aunque con tendencia de crecimiento. De once municipios, la hipótesis de investigación fue confirmada sólo para Marabá y Paragominas.

Palabras clave: gastos públicos municipales; gestión ambiental; estado de Pará; descentralización; esfuerzo financiero.

\section{LA GESTION ENVIRONNEMENTALE DES MUNICIPALITÉS DE PARÁ PROVINCE: DÉPENSES PUBLIQUES, DÉCENTRALISATION ET DURABILITÉ}

Depuis les années 1980, la gestion de l'environnement au Brésil a connu un processus de décentralisation et d'augmentation du nombre de pouvoirs municipaux, également en cours dans l'État de Pará. Ce papier vise à évaluer l'évolution historique et l'engagement financier des dépenses publiques consacrées à l'environnement dans répondeur à la question suivante: la décentralisation de la gestion municipale paraense s'est-elle accompagnée d'une augmentation proportionnelle de l'engagement des dépenses environnementales? La méthodologie a consisté en une analyse des dépenses environnementales des municipalités de Pará, de leur transparence et de leur tendance à la croissance, en plus d'une focalisation sur les groupes définis par le Programme Municipalités Vertes. L'hypothèse émise était que les municipalités mieux structurées présentaient un meilleur engagement de la gestion financière environnementale. Les résultats montrer l'insuffisance et la faible transparence, avec aggravation des années électorales, des dépenses environnementales municipales, bien qu'avec une tendance à la croissance. De 11 municipalites, I'hypothèse de recherche solement été confirmée dans Marabá et Paragominas.

Mots-clés: dépenses publiques municipales; gestion environnementale; État de Pará; décentralisation; engagement financière.

JEL: H76.

\section{INTRODUÇÃO}

No Brasil, o art. 225 da Constituição Federal de 1988 (CF/1988) considera, em seu caput, que "Todos têm direito ao meio ambiente ecologicamente equilibrado, bem como de uso comum do povo e essencial à sadia qualidade de vida, impondo-se ao Poder Público e à coletividade o dever de defendê-lo e preservá-lo para as presentes e futuras geraçóes" (Brasil, 1988, art. 255). O fato de o meio ambiente ecologicamente equilibrado ser um direito difuso faz com que muitos autores considerem que o poder público é o principal agente promotor, regulamentador e financiador da política ambiental (Beltráo, 2009; Tridapalli et al., 2010; Dantas et al., 2014). 
A gestão pública ambiental brasileira tem passado por um processo de descentralização (Idesp, 2011), inaugurado com a Política Nacional de Meio Ambiente - PNMA (Lei Federal no 6.938/1981). Desde então, os municípios brasileiros estão assumindo um número cada vez maior de atribuiçóes da política ambiental e ampliando suas estruturas organizacionais na área de meio ambiente - secretarias, conselhos, fundos etc. (Guandalini, Borinelli e Godoy, 2013). Este avanço também tem se verificado no estado do Pará, por meio de um conjunto de açóes, por parte do governo e da sociedade civil, que visam à estruturação e ao fortalecimento dos sistemas municipais de meio ambiente (Idesp, 2011).

Ainda no estado do Pará, destaca-se a criação do PMV, criado em 2008 pelo governo estadual em parceria com alguns municípios paraenses, a sociedade civil, a iniciativa privada, o Instituto Brasileiro do Meio Ambiente e Recursos Naturais Renováveis (Ibama) e o Ministério Público Federal (MPF). Este programa tem como objetivo promover a produção rural sustentável mediante ações estratégicas de ordenamento ambiental e fundiário e também de gestão ambiental, focando em pactos locais, no monitoramento ambiental, na implantaçáo do Cadastro Ambiental Rural (CAR) e na estruturação da gestão ambiental dos municípios (Costa e Fleury, 2015; Estado do Pará, [s.d.]).

Por outro lado, existe a necessidade de que esse processo de descentralização seja acompanhado de maior estabilidade financeira, uma vez que um dos maiores problemas enfrentados pelos municípios, no que diz respeito à gestão ambiental, está no aumento de responsabilidades sem aumento proporcional dos recursos financeiros destinados para atendimento destas demandas (Mauro, 2007).

Nesse sentido, este trabalho tem como objetivo avaliar a evolução histórica dos gastos públicos em gestão ambiental nos municípios paraenses no período de 2000 a 2011. Por meio desta avaliação, pretende-se responder aos seguintes questionamentos: a evolução dos gastos públicos em gestão ambiental tem sido suficiente para atender ao aumento das atribuiçóes ambientais aos municípios paraenses? Quais grupos de municípios têm apresentado melhor empenho financeiro em gestão ambiental? A hipótese levantada foi de que os municípios com melhor estrutura apresentaram melhor empenho da gestão ambiental. Antes de adentrar nesta questão, porém, será feita uma breve discussão sobre o processo de descentralizaçáo e o financiamento público da gestão ambiental no Brasil.

\section{A DESCENTRALIZAÇÃO DA GESTÃO AMBIENTAL}

A descentralizaçáo pode ser entendida como a transferência de autonomia de unidades administrativas agregadas, como o governo federal, para unidades menores, como municípios e comunidades (Buarque, 1999). Desde a década de 1980, sob influência da doutrina liberal e visando à redução da legitimação do estado central, 
a descentralização tem se estabelecido como uma tendência nos governos mundiais, e, no Brasil, tem ocorrido nas mais diversas áreas, como saúde, educação, assistência social e habitação (Scardua, 2003; Scardua e Bursztyn, 2003).

$\mathrm{Na}$ área de meio ambiente, o processo de descentralização foi inaugurado com a PNMA, que instituiu o Sistema Nacional de Meio Ambiente (Sisnama), composto por todos os entes federativos e fundaçóes instituídas pelo poder público (Idesp, 2011). Outros dispositivos legais que atuaram neste sentido foram: a Resolução no 237/1997, do Conselho Nacional de Meio Ambiente (Conama), e a Lei Federal no 7.804/1989, que trataram da descentralização das açóes de licenciamento ambiental e de fiscalização; e a própria Constituição Federal de 1988, que delegou à União, aos estados, ao Distrito Federal e aos municípios “a competência comum de proteger o meio ambiente e combater a poluição em qualquer de suas formas, assim como preservar as florestas, a fauna e a flora" (Brasil, 1988, art. 23). A Lei Complementar (LC) no 140/2011, por outro lado, atribuiu diferentes açóes administrativas para os entes federados (quadro 1).

QUADRO 1

Ações administrativas nas questões ambientais conforme os entes federados: União, estados e municípios, de acordo com a LC no 140/2011

\begin{tabular}{|c|c|c|}
\hline União & Estados & Municípios \\
\hline \multirow{2}{*}{$\begin{array}{l}\text { Política Nacional do Meio Ambiente em } \\
\text { nível nacional: planejamento, execução, } \\
\text { monitoramento, integração com as } \\
\text { outras políticas, os outros países e os } \\
\text { demais entes federados (art. 7ํㅗ I-VIII). }\end{array}$} & $\begin{array}{l}\text { Política Nacional do Meio Ambiente: fazer } \\
\text { cumprir no nível estadual (art. } 8 \circ \text { I). }\end{array}$ & $\begin{array}{l}\text { Políticas Nacional e Estadual do Meio } \\
\text { Ambiente: fazer cumprir no nível munici- } \\
\text { pal (art. 9o, I). }\end{array}$ \\
\hline & $\begin{array}{l}\text { Política Estadual de Meio Ambiente: } \\
\text { planejamento, execução, monitoramento, } \\
\text { integração com outras políticas e entes } \\
\text { federados (art. } 8^{\circ}, \text { II-VII). }\end{array}$ & $\begin{array}{l}\text { Política Municipal de Meio Ambiente: } \\
\text { planejamento, execução, monitoramento, } \\
\text { integração com outras políticas e entes } \\
\text { federados (art. 9o, II-VII). }\end{array}$ \\
\hline \multirow{2}{*}{$\begin{array}{l}\text { Sinima: organizar e manter, com a } \\
\text { colaboração dos órgãos e entidades da } \\
\text { administração pública dos estados, do } \\
\text { Distrito Federal e dos municípios. }\end{array}$} & $\begin{array}{l}\text { Sistema Estadual de Informação sobre } \\
\text { Meio Ambiente: organizar e manter, com } \\
\text { a colaboração dos órgãos e entidades da } \\
\text { administração pública dos estados e dos } \\
\text { municípios (art. 8ํ, VII). }\end{array}$ & $\begin{array}{l}\text { Sistema Municipal de Informações sobre } \\
\text { Meio Ambiente: organizar e manter (art. } \\
90, \text { VIII). }\end{array}$ \\
\hline & $\begin{array}{l}\text { Sinima: prestar informação à União (art. } \\
\text { 8@, VIII). }\end{array}$ & $\begin{array}{l}\text { Sistemas Estadual e Nacional de Infor- } \\
\text { mações sobre Meio Ambiente: prestar } \\
\text { informações aos estados e à União (art. } \\
\text { 9o, VIII). }\end{array}$ \\
\hline $\begin{array}{l}\text { Zoneamento ambiental em âmbito } \\
\text { nacional e regional. }\end{array}$ & $\begin{array}{l}\text { Zoneamento ambiental em âmbito estadual, } \\
\text { em conformidade com o nacional e os } \\
\text { estaduais (art. } 8^{\circ}, \text { IX). }\end{array}$ & $\begin{array}{l}\text { Zoneamento ambiental no plano diretor } \\
\text { em âmbito municipal, em conformidade } \\
\text { com o nacional e o estadual (art. }{ }^{\circ}{ }^{\circ} \\
\text { IX-X). }\end{array}$ \\
\hline $\begin{array}{l}\text { Educação ambiental no âmbito federal } \\
\text { (art. 7ọ, XI). }\end{array}$ & $\begin{array}{l}\text { Educação ambiental no âmbito estadual } \\
\text { (art. 8ํ, XI). }\end{array}$ & $\begin{array}{l}\text { Educação ambiental no âmbito municipal } \\
\text { (art. } 9 \stackrel{0}{ }, \mathrm{XI}) \text {. }\end{array}$ \\
\hline
\end{tabular}


(Continuação)

\begin{tabular}{|c|c|c|}
\hline União & Estados & Municípios \\
\hline $\begin{array}{l}\text { Licenciamento ambiental no nível nacio- } \\
\text { nal de empreendimentos desenvolvidos: } \\
\text { conjuntamente, no Brasil e em país limí- } \\
\text { trofe; no mar territorial, na plataforma } \\
\text { continental ou na zona econômica exclu- } \\
\text { siva; em terras indígenas; em unidades } \\
\text { de conservação instituídas pela União, } \\
\text { exceto em áreas de proteção ambiental; } \\
\text { em dois ou mais estados; de caráter } \\
\text { militar; que trate de material radioativo } \\
\text { (art. 7־ , XIV). }\end{array}$ & $\begin{array}{l}\text { Licenciamento ambiental no nível } \\
\text { estadual de empreendimentos localizados } \\
\text { no estado ou em unidades de conservação } \\
\text { instituídas pelo estado (art. 8o, XIV-XV). }\end{array}$ & $\begin{array}{l}\text { Licenciamento ambiental no nível } \\
\text { municipal de empreendimentos nos } \\
\text { seguintes casos: } i \text { ) que causem ou } \\
\text { possam causar impacto ambiental de } \\
\text { âmbito local, conforme tipologia definida } \\
\text { pelos respectivos conselhos estaduais de } \\
\text { meio ambiente, considerando os critérios } \\
\text { de porte, potencial poluidor e natureza da } \\
\text { atividade; e ii) localizados em unidades } \\
\text { de conservação instituídas pelo município } \\
\text { (art. 9o- XIV). }\end{array}$ \\
\hline $\begin{array}{l}\text { Manejo florestal em âmbito nacional } \\
\text { (Art. } 7 \circ, \mathrm{XV} \text { ) }\end{array}$ & $\begin{array}{l}\text { Manejo florestal em âmbito estadual (art. } \\
\text { 8o, XVI). }\end{array}$ & $\begin{array}{l}\text { Manejo florestal em âmbito municipal } \\
\text { (art. 9o, XV). }\end{array}$ \\
\hline $\begin{array}{l}\text { Monitoramento da fauna/flora em } \\
\text { extinção, da invasão de espécies } \\
\text { exóticas e do patrimônio genético (art. } \\
\text { 7ํ, XVI-XXV) }\end{array}$ & $\begin{array}{l}\text { Monitoramento da fauna e da flora em } \\
\text { extinção no âmbito estadual (art. 8ㅇ, } \\
\text { XVII-XX). }\end{array}$ & \\
\hline
\end{tabular}

Fonte: Brasil (2011).

Elaboração dos autores.

Entre as atribuiçóes municipais definidas na LC no 140/2011, destacam-se: i) o planejamento, a execução e o monitoramento da Política Municipal de Meio Ambiente; ii) a organização e a manutenção do Sistema Municipal de Meio Ambiente; iii) a instalação do zoneamento ambiental em conformidade com o Plano Diretor Municipal; iv) o licenciamento ambiental para atividades que causam impacto local e em unidades de conservação instituídas pelo município; e $v$ ) o manejo florestal no âmbito municipal.

Discutindo o processo de descentralização da gestão ambiental no Brasil, Scardua e Bursztyn (2003) apontam os seguintes riscos: $i$ ) grandes diferenças entre os municípios, de modo que a imposição de atribuições pode ter resultados diferentes conforme suas capacidades institucionais; $i$ ) o aumento das oportunidades de corrupção pela transferência do poder das elites nacionais para as elites locais; iii) o revigoramento do coronelismo, de modo que a descentralizaçáo pode ser instrumentalizada para a concentração do poder pelas oligarquias locais. Neste último ponto, os autores ressaltam a necessidade de incentivo a participaçấo social:

As práticas clientelistas e coronelistas, ligadas a questôes políticas locais, poderão influenciar a forma de atuação dos órgãos municipais de meio ambiente, possibilitando maior desagregaçáo e gerando externalidades negativas para a área ambiental. Caso o processo de descentralização não seja tocado de forma articulada com a participação ativa da populaçáo e de órgãos de controle social, como o Ministério Público, tais práticas não poderão ser vencidas (Scardua e Bursztyn, 2003, p. 307).

Ainda para Scardua e Bursztyn (2003), a descentralização da gestão ambiental no Brasil tem ocorrido de forma descontínua no tempo e no espaço, o que pode ser atribuído aos seguintes fatores: 
(...) falta de técnicos nos órgãos estaduais e municipais de meio ambiente; falta de capacitação e treinamento; salários defasados, quando comparados aos praticados pela iniciativa privada; instituiçōes despreparadas para assumir atividades ambientais; carência de recursos financeiros e de infraestrutura; ausência de instrumentos de gestáo ambiental ou instrumentos ultrapassados, dentre outros (Scardua e Bursztyn, 2003, p. 308, grifo nosso).

Como se pode observar, os autores reconhecem a necessidade de recursos financeiros como um dos pilares para que o processo de descentralização da gestão ambiental seja bem-sucedido.

\section{GASTOS PÚBLICOS EM MEIO AMBIENTE}

As finanças públicas no Brasil estão regulamentadas por um conjunto de leis nas três esferas de governo, a saber: o Plano Plurianual (PPA) dos programas e açóes de governo; a Lei de Diretrizes Orçamentárias (LDO), com as metas e as prioridades da administração pública; e a Lei Orçamentária Anual (LOA), com a previsão das receitas e despesas a serem realizadas no ano de vigência. Os gastos públicos agrupam-se por "funçóes", segundo a Portaria no 42/1999 do Ministério do Planejamento, Desenvolvimento e Gestão (MPDG), de modo que a função 18 corresponde à "gestâo ambiental", e pode ser definida como "o conjunto de açóes desenvolvidas para a proteçáo de recursos naturais, monitoramento por meio de levantamento sistemático de dados oceanográficos, meteorológico, astronômicos e geofísicos, e controle das condiçóes ambientais" (Guandalini, Borinelli e Godoy, 2013, p. 209).

De grande importância também é a LC nº 101/2000 - Lei de Responsabilidade Fiscal (LRF) -, que tem como um de seus pilares a transparência das contas públicas, conforme seu art. 48:

"Parágrafo único. A transparência será assegurada mediante: (...) II - liberaçáo ao pleno conhecimento e acompanhamento da sociedade, em tempo real, de informaçóes pormenorizadas sobre a execuçáo orçamentária e financeira, em meios eletrônicos de acesso público" (Brasil, 2000a, art. 48).

Também no que diz respeito à transparência, o acesso à informação constitui um dos instrumentos adotados pela PNMA, conforme seu art 9o: "São instrumentos da Política Nacional do Meio Ambiente: (...) XI - a garantia da prestaçáo de informaçóes relativas ao Meio Ambiente, obrigando-se o Poder Público a produzi-las, quando inexistentes" (Brasil, 1981, art. 9을.

Shih (2010) considera que existe uma estrita correlação entre o grau de transparência tanto com a redução da corrupção como com o aumento da confiança das pessoas no governo. Segundo Hendriksen e Breda (1999), no entanto, para que a transparência exista de fato é necessário que as informaçóes sejam divulgadas de forma acessível (de fácil compreensão) e completa. Além disso, a transparência é imprescindível para promoção da participação social, o que, por sua vez, é necessário 
para viabilidade do processo de descentralização da gestão ambiental, conforme Bursztyn e Bursztyn (2012, p. 173):

Mediante transparência, os atores sociais podem ter acesso a informaçóes que são cruciais não apenas ao seu esclarecimento sobre processos em curso, mas também sobre aspectos gerenciais, como lisura e efetividade. Geralmente, sistemas de decisão transparentes têm procedimentos claros de informação e decisão, e dispóem de canais de comunicação entre atores e operadores, nos dois sentidos.

O exercício do direito à informação requer que os fluxos sejam atualizados e inteligíveis. Não basta transparência no sentido de acesso livre. É preciso também que os códigos de comunicação se deem em linguagem compreensível. Entretanto, isso nem sempre ocorre, pois tende a prevalecer o jargão técnico.

Apesar de avanços no acesso à informação, a disponibilidade de dados de despesas públicas ambientais no Brasil ainda é baixa em termos de séries históricas, de modo que os estudos acerca dos gastos ambientais públicos iniciaram-se nos anos 1990, com destaque para o nível federal, ao passo que ainda existem poucos estudos sobre estes gastos no nível municipal, sobretudo na região Norte (Carneiro, Moura e Gouveia Neto, 2013; Nina e Szlafsztein, 2014; Tridapalli et al., 2010). Os gastos em gestão ambiental, no geral, não ultrapassam $1 \%$ do total dos gastos públicos (tanto em termos federais quanto em termos estaduais e municipais) situação análoga ao que ocorre nos países em desenvolvimento (na China e nos outros países da América Latina, por exemplo), enquanto que nos países europeus, a proporção dos gastos ambientais é consideravelmente maior (Tridapalli et al., 2010; Bueno, Oliana e Borinelli, 2013; Dantas et al., 2014).

Picoli (2011) considera que os gastos públicos ambientais no Brasil tiveram um significativo aumento a partir de 2000, impulsionado pela Lei no 9.985/2000 (Brasil, 2000b), que estabeleceu o Sistema Nacional de Unidades de Conservação (SNUC) e estimulou a criação de áreas protegidas sob regime das três esferas da administração pública (federal, estadual e municipal). Para a autora, no entanto, os gastos públicos ainda são insuficientes e "estâo aquém dos gastos ideais gerando o que denominamos de Hiato de Sustentabilidade, que nada mais é do que uma lacuna entre o que investimos e o que deveríamos investir" (Picoli, 2011, p. 7).

De fato, muitos autores consideram que os gastos ambientais no Brasil são insuficientes diante das demandas existentes, além de serem muito vulneráveis aos cortes orçamentários (Young, 2005; Borinelli et al., 2011). Nina e Szlafsztein (2014), por exemplo, apontam que as despesas em meio ambiente do governo do estado do Pará estiveram entre as que mais reduziram, entre 2000 e 2012, em relação à sua previsão orçamentária, com a concretização de riscos fiscais, como desastres naturais - justamente fenômenos que poderiam ser minimizados por uma gestão ambiental mais eficiente. 


\section{METODOLOGIA}

A primeira etapa metodológica consistiu no levantamento das despesas públicas, realizadas por 143 municípios paraenses, destinadas à função "gestão ambiental", em termos proporcionais em relação às despesas totais, no período de $2002 \mathrm{a}$ 2011, feita no site do Tesouro Nacional (Brasil, 2013). Atualmente, o estado do Pará possui 144 municípios, mas, no contexto deste trabalho, o município de Mojuí dos Campos, criado em 2008 e que não apresentou dados financeiros em gestão ambiental, não foi incluído na série amostral. $\mathrm{O}$ trabalho se limita aos anos de 2002 a 2011, uma vez que, no site do Tesouro Nacional, os dados contábeis para os anos de 2012 a 2018 ainda não estavam disponíveis no período em que foi realizada a pesquisa.

A segunda etapa metodológica foi a classificação dos municípios, quanto ao empenho da gestão financeira ambiental, mediante três critérios (quadro 2), conforme a seguir descrito.

1) Média do percentual dos gastos ambientais em relação ao total dos gastos para o período estudado, um indicador bastante utilizado em outros estudos de análise de gastos públicos (Tridapalli et al., 2010; Dantas et al., 2014; Nina e Szlafsztein, 2014). O uso da média em análises estatísticas, no entanto, tem sido muito criticado, uma vez que não leva em conta variaçóes temporais e/ou transversais das amostras (Becker, 2007; Bell e Morse, 2008). Para contornar este problema, fez-se também uma análise do coeficiente de variação dos gastos ambientais municipais, além dos outros indicadores explicados adiante.

2) O número de anos em que foram apresentados os gastos na função "gestáo ambiental", o que se traduz num indicador de transparência dos gastos públicos, de relevância já ressaltada pela LC nํㅜ 101/2000 e pela Política Nacional de Meio Ambiente (Lei no 6.938/1981). Indicadores análogos aos adotados neste trabalho foram usados por Carneiro, Moura e Gouveia Neto (2013), Serpa (2014), Couto e Frey (2017) e Guandalini, Borinelli e Godoy (2013).

3) A tendência de crescimento dos gastos em meio ambiente, um indicador ainda pouco adotado na literatura brasileira, mas de grande relevância. Lomborg (2004), por exemplo, considera que o foco das análises estatísticas das questóes ambientais deve se centrar nas tendências, uma vez que elas denotam a evolução histórica dos fenômenos os quais se pretende estudar.

A terceira etapa consistiu na análise por grupo de municípios, adotando a metodologia do PMV, que divide os municípios paraenses em quatro grupos (mapa 1; quadro 3). Em seguida, passou-se a analisar, grupo a grupo, o percentual de municípios para cada um dos empenhos definidos no quadro 2 . 


\section{QUADRO 2}

Classes definidas para os municípios ${ }^{1}$

\begin{tabular}{|c|c|c|c|}
\hline \multirow{2}{*}{ Empenho da gestão ambiental financeira } & \multicolumn{3}{|c|}{ Critérios } \\
\hline & Média $^{2}$ & Anos com dados ${ }^{3}$ & Tendência \\
\hline \multirow{2}{*}{ Ótimo } & $>1,15$ & + de 8 & Positiva \\
\hline & $>0,57 ;<1,15$ & + de 8 & Positiva \\
\hline \multirow{3}{*}{ Bom } & $<0,57$ & + de 8 & Positiva \\
\hline & $>1,15$ & 8 ou - & Positiva \\
\hline & $>1,15$ & + de 8 & Negativa \\
\hline \multirow{2}{*}{ Regular } & $>0,57 ;<1$ & 8 ou - & Positiva \\
\hline & $>0,57 ;<1$ & + de 8 & Negativa \\
\hline \multirow{3}{*}{ Ruim } & $<0,57$ & 8 ou - & Positiva \\
\hline & $<0,57$ & + de 8 & Negativa \\
\hline & $>1,15$ & 8 ou - & Negativa \\
\hline \multirow{2}{*}{ Péssimo } & $>0,57 ;<1$ & 8 ou - & Negativa \\
\hline & $<0,57$ & 8 ou - & Negativa \\
\hline
\end{tabular}

Fonte: Finbra - Dados Contábeis dos Municípios - 1989 a 2012.31 jan. 2013. Disponível em: <https://bit.ly/3lp243z>. Acesso em: 20 jul. 2020.

Elaboração dos autores.

Notas: 'Conforme os critérios: i) média do percentual dos gastos públicos em gestão ambiental em relação ao total dos gastos; ii) número de anos em que foram apresentados os gastos em gestão ambiental; e iii) tendência de crescimento dos gastos em gestão ambiental.

${ }^{2}$ Os limites de $0,57 \%$ e 1,15\% correspondem aos valores aproximados de um terço e dois terços da amplitude da média dos percentuais gastos em gestão ambiental pelos municípios estudados. Estas médias variaram de $0 \%$ a 1,72\%.

${ }^{3}$ No caso do limite de anos (oito), o critério foi arbitrário.

\section{QUADRO 3}

\section{Grupos dos municípios paraenses adotados pelo PMV}

\begin{tabular}{|l|l|l|}
\hline \multicolumn{1}{|c|}{ Grupos } & \multicolumn{1}{|c|}{ Municípios } & \multicolumn{1}{c|}{ Descrição dos municípios } \\
\hline Embargados & $16(11 \%)$ & $\begin{array}{l}\text { Inclusos na lista do Ministério do Meio Ambiente como os que mais } \\
\text { desmataram a Amazônia nos últimos anos, tendo suas atividades pro- } \\
\text { dutivas embargadas, de modo que as principais medidas ambientais } \\
\text { desenvolvidas são de recuperação. }\end{array}$ \\
\hline Pressionados & $19(13 \%)$ & $\begin{array}{l}\text { Localizados sob influência de grandes projetos no estado, tendo, } \\
\text { como foco principal, desenvolver atividades econômicas sustentáveis, } \\
\text { ou seja, de conservação. }\end{array}$ \\
\hline Consolidados & $80(56 \%)$ & $\begin{array}{l}\text { Possuem cobertura florestal original que abrange aproximadamente } \\
\text { 30\% do território, tendo como foco desenvolver sua economia com } \\
\text { atividades de recuperação florestal. }\end{array}$ \\
\hline Base Florestal & $28(20 \%)$ & $\begin{array}{l}\text { Possuem 70\% de sua cobertura florestal ainda original, de modo que } \\
\text { as principais atividades a serem desenvolvidas são de preservação. }\end{array}$ \\
\hline
\end{tabular}

Fonte: Idesp (2011).

Elaboração dos autores.

Obs.: Nos parênteses, há o percentual do estado. 


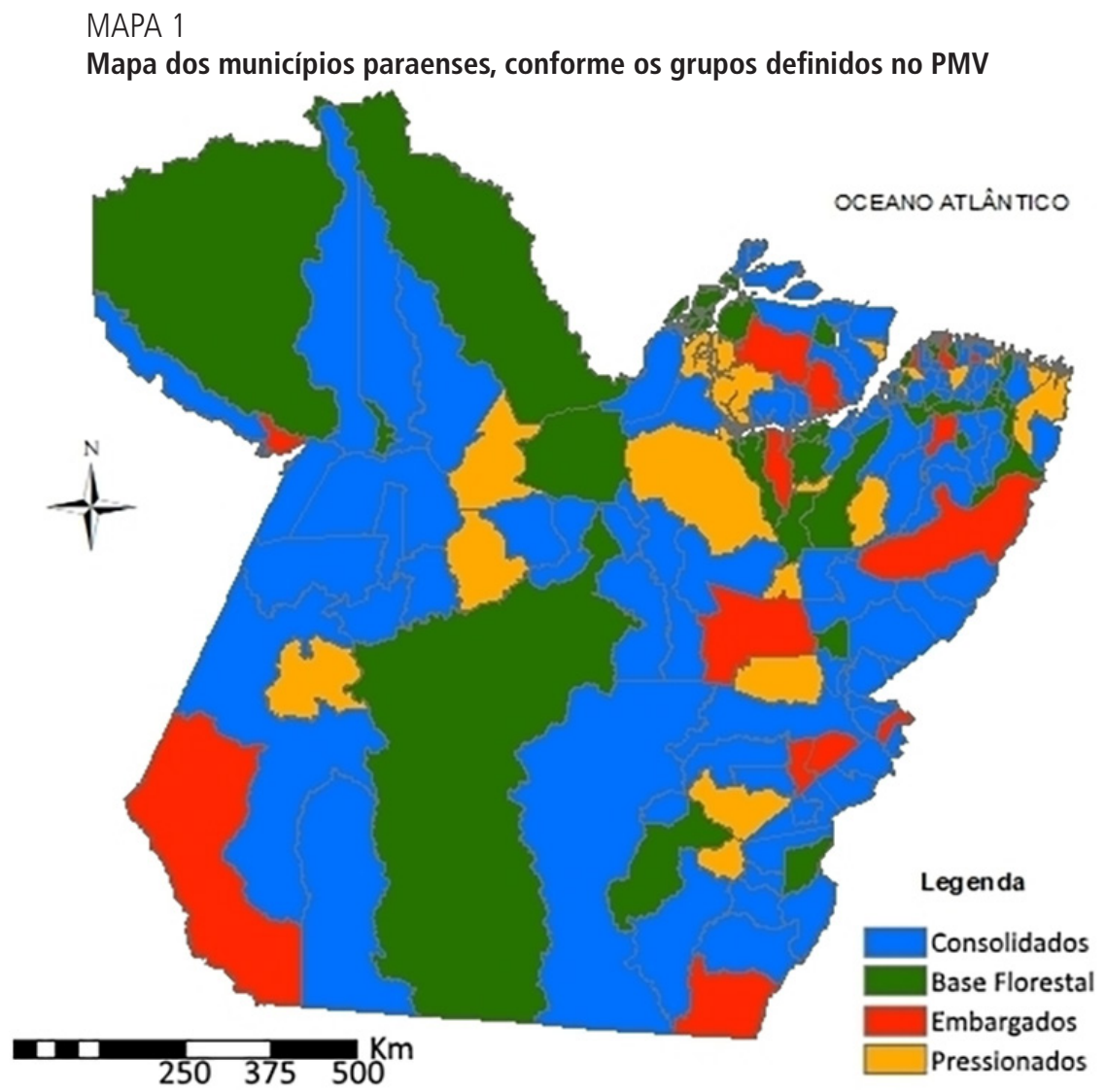

Fonte: Idesp (2011).

Por fim, foi realizada uma análise focalizada dos municípios com capacidade completa de gestão ambiental estabelecida pelo relatório do Idesp (2011), ou seja, aqueles que possuíam, à época da pesquisa, um Fundo Municipal de Meio Ambiente (FMMA) ativo e um Conselho Municipal de Meio Ambiente (CMMA) ativo, paritário e deliberativo. A hipótese de pesquisa levantada é de que estes municípios apresentaram um empenho ótimo de gestão ambiental financeira, uma vez que eles eram os que possuíam a melhor capacidade e a maior quantidade de atribuiçôes institucionais (Idesp, 2011).

\section{RESULTADOS E DISCUSSÕES}

\subsection{Transparência dos gastos ambientais municipais}

Um importante fator para a gestão ambiental é a disponibilidade dos dados municipais para monitoramento e avaliação. O primeiro resultado a ser destacado para o período estudado é a falta de transparência, no que tange aos gastos públicos em 
gestão ambiental, por parte significativa dos municípios paraenses. O percentual de municípios para o qual os dados destas despesas estavam disponíveis variou bastante (gráfico 1), na amplitude de cerca de 61\%, em 2008, chegando a $98 \%$, em 2006 (a média foi de 82,5\%).

Esse resultado vai ao encontro do obtido por Guandalini, Borinelli e Godoy (2013), que apontam a baixa transparência dos dados coletados no site do Tesouro Nacional, uma vez que muitos municípios ainda não adequaram seus relatórios contábeis às normas da Portaria no 42/1999. Além disso, percebeu-se que os picos negativos em relação às informaçóes municipais ocorreram em anos de eleições municipais - 2004 e 2008 - (gráfico 1), indicando uma possível influência política nestes balanços financeiros. É provável que mudanças de governo façam com que se perca o interesse na realização do balanço orçamentário da gestão anterior.

Estudando as variaçóes das despesas públicas nas capitais dos estados brasileiros, Guandalini, Borinelli e Godoy (2013) também perceberam a influência política, mas no sentido de aumento dos gastos em meio ambiente, conforme a seguir.

(...) cabe desatacar que nos anos eleitorais (2004 e 2008) os gastos ambientais cresceram substancialmente e no ano subsequente os mesmos apareceram em queda, o que pode indicar que nas capitais as questóes ambientais recebem alguma prioridade no conjunto de questóes relevantes para a população, dado também que os problemas ambientais são percebidos como mais graves nestas cidades. Apesar de a Lei de Responsabilidade Fiscal ter criado alguns dispositivos para impedir o aumento de gastos públicos e o endividamento dos governos nos anos eleitorais, essa prática continua acontecendo (Guandalini, Borinelli e Godoy, 2013, p. 211). 
GRÁFICO 1

Municípios que disponibilizam os gastos em gestão ambiental no site do Tesouro Nacional (2002-2011)

(Em \%)

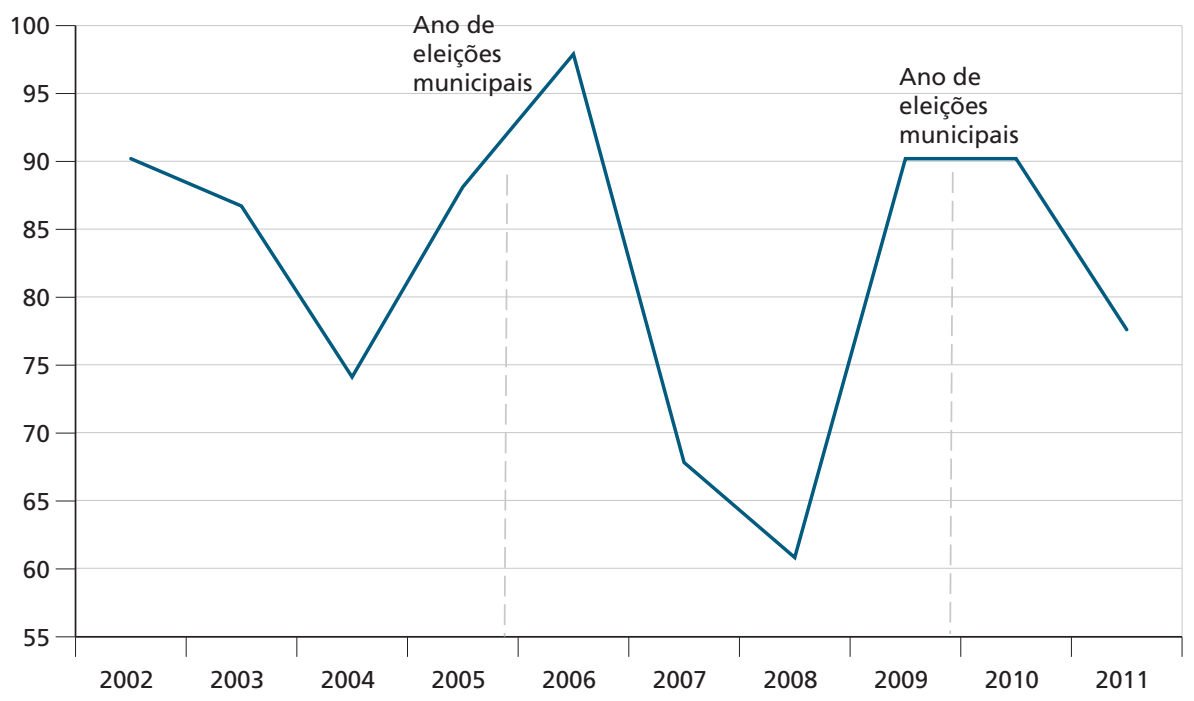

Fonte: Finbra - Dados Contábeis dos Municípios - 1989 a 2012. 31 jan. 2013. Disponível em: <https://bit.ly/3lp243z>. Acesso em: 20 jul. 2020.

Elaboração dos autores.

No Pará, percebe-se que o descumprimento da LRF, em questôes ambientais, ocorre muito mais pelo desrespeito ao princípio da informação. Considerando o exercício de 2008, constatou-se que a média populacional é maior para os municípios que não disponibilizaram seus balanços orçamentários em meio ambiente (46.934,54 habitantes) do que para os municípios que o fizeram (35.441,73 habitantes). Isso indica que, no Pará, não necessariamente o maior tamanho populacional do município implica maior preocupação com a gestão ambiental. Este resultado contradiz a hipótese levantada por Guandalini, Borinelli e Godoy (2013), baseada na análise dos gastos ambientais das capitais brasileiras.

\subsection{Média, crescimento e coeficiente de variação dos gastos ambientais municipais}

A média dos gastos públicos em meio ambiente dos municípios do Pará, em proporção aos gastos totais municipais, foi de $0,33 \%$, um valor muito abaixo de outras realidades brasileiras. Comparando com os resultados obtidos por Tridapalli et al. (2010) e por Dantas et al. (2014), por exemplo, podem-se destacar maiores percentuais médios para o Brasil quando considerados municípios, estados e Uniáo; para os estados brasileiros (0,59\%); e para o próprio estado do Pará $(0,53 \%)$. Também apresentam maiores valores as médias: dos municípios 
brasileiros (0,81\%); dos estados da Paraíba (1,22\%), do Espírito Santo $(1,14 \%)$ e do Paraná $(1,12)$; e da maioria dos municípios paranaenses, como Londrina (2,51\%), Cascavel (7,32\%) e São José dos Pinhais (5,42\%). Foram poucos os casos em que os percentuais de gastos ambientais foram menores do que os dos municípios paraenses, destacando-se: a própria União $(0,22 \%)$ e os estados do Mato Grosso (0,20\%), da Bahia (0,23\%) e de Roraima (0,21\%) (tabela 1$)$.

TABELA 1

Média dos percentuais de gastos ambientais, em relação ao total de gastos, dos municípios paraenses em comparação com as médias encontradas para outros entes governamentais em outros estudos (2002-2011)

\begin{tabular}{lllll}
\hline & \multicolumn{1}{c}{ Localização } & $\begin{array}{c}\text { Gastos ambientais } \\
(\%)\end{array}$ & Fonte & Período \\
\hline Municípios do estado do Pará & & 0,33 & Este estudo & 2002-2011 \\
& Pará & 0,53 & & \\
& Mato Grosso & 0,20 & & \\
Governos estaduais & Bahia & 0,23 & & \\
& Roraima & 0,21 & & \\
& Paraíba & 1,22 & Tridapalli et al. 2002-2008 \\
& Espírito Santo & 1,14 & (2010) & \\
Municípios do Paraná & Paraná & 1,12 & & \\
& Londrina & 2,51 & & \\
Brasil & Cascavel & 7,32 & & \\
Municípios do Brasil & São José dos Pinhais & 5,42 & & \\
Estados do Brasil & & 0,36 & & \\
União & & 0,81 & Dantas et al. & 2004-2011 \\
\hline
\end{tabular}

Fonte: Tridapalli et al. (2010); e Dantas et al. (2014).

Elaboração dos autores.

Apesar da baixa média, o percentual dos gastos ambientais dos municípios paraenses tem apresentado tendência de crescimento, passando de $0,25 \%$, em 2002, para $0,41 \%$, em 2011, com pico de $0,44 \%$ em 2009 - o que representa uma taxa de crescimento aritmético de $8,44 \%$ ao ano - a.a. (gráfico 2). Em comparação com o estudo realizado por Neves (2013), constata-se que este valor é maior do que a taxa de crescimento do percentual de municípios paraenses com Órgãos Municipais de Meio Ambiente (OMMA), que é de 3,32\% a.a., de 2002 a 2009. No mesmo período, no entanto, outros componentes da gestáo ambiental cresceram em um ritmo mais acelerado. Os CMMAs cresceram a uma taxa de $11,34 \%$ a.a.; os FMMAs, a uma taxa de $828,57 \%$ a.a.; e o Arranjo Institucional Completo, que inclui OMMA, CMMA e FMMA, com taxa de 628,57\% a.a. Nestes dois últimos, 
no entanto, a alta taxa de crescimento está relacionada ao fato de que abrangiam apenas $0,7 \%$ dos municípios paraenses em 2002. Outro componente que tem crescido com taxa mais rápida que os percentuais dos gastos em meio ambiente é o número médio de profissionais por município, que aumentou cerca de 13,96\% a.a. no período de 2002 a 2008 (tabela 2).

Dessa forma, pode-se dizer que o crescimento dos gastos públicos em meio ambiente no estado do Pará não esteve alinhado com o crescimento dos outros componentes institucionais da gestão ambiental, ou seja, não vem acompanhando o processo de descentralização, nem tem sido suficiente para atender ao aumento das atribuiçóes ambientais aos municípios.

\section{GRÁFICO 2}

Média' dos percentuais de gastos em meio ambiente em relação ao total de gastos nos municípios paraenses (2002-2011)

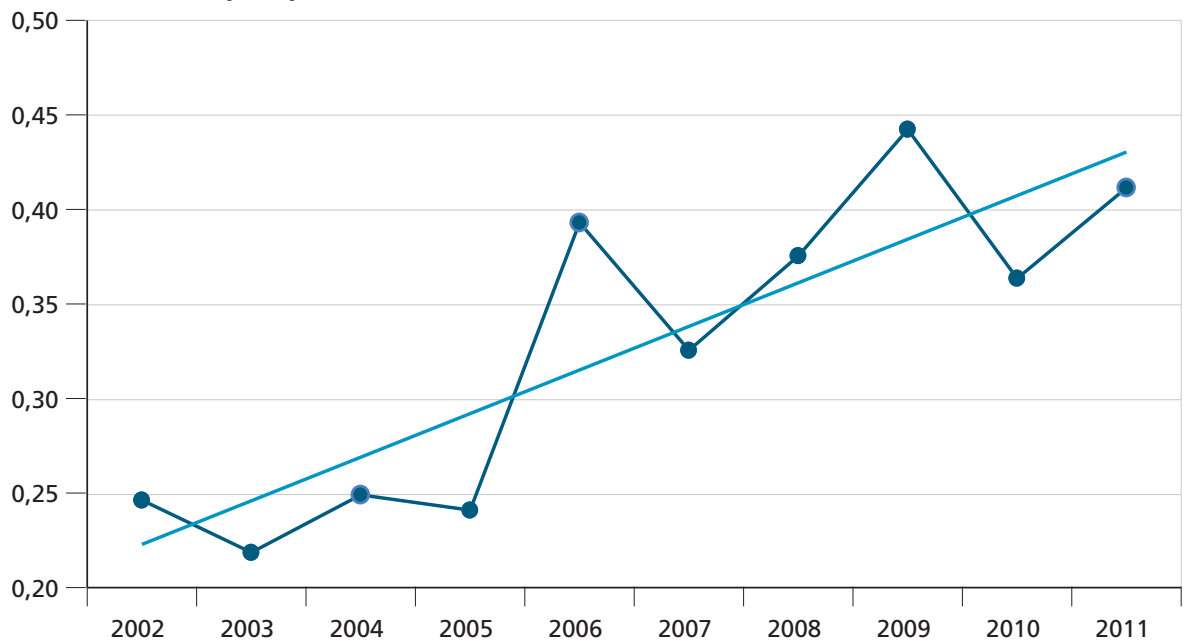

Fonte: Finbra - Dados Contábeis dos Municípios - 1989 a 2012. 31 jan. 2013. Disponível em: <https://bit.ly/3|p243z>. Acesso em: 20 jul. 2020.

Elaboração dos autores.

Nota: ${ }^{1}$ Média calculada pela equação $y=0,0231 x+0,1998 ; R^{2}=0,7281$.

Obs.: A linha vermelha corresponde à tendência linear.

\section{TABELA 2}

Caracteristicas gerais dos componentes da gestão ambiental dos municípios paraenses (2002-2011)

\begin{tabular}{lcccc}
\hline \multicolumn{1}{c}{ Componente da gestão ambiental } & Período & $\begin{array}{c}\text { Ano inicial } \\
(\%)\end{array}$ & $\begin{array}{c}\text { Ano final } \\
(\%)\end{array}$ & $\begin{array}{c}\text { Crescimento anual } \\
(\%)\end{array}$ \\
\hline Municípios com OMMA & $2002-2009$ & 78,3 & 96,5 & 3,32 \\
Municípios com CMMA & $2002-2009$ & 23,8 & 42,7 & 11,34 \\
Municípios com FMMA & $2002-2009$ & 0,7 & 41,3 & 828,57 \\
Municípios com Arranjo Institucional Completo & $2002-2009$ & 0,7 & 31,5 & 628,57 \\
\hline
\end{tabular}




\begin{tabular}{lcccc}
\hline \multicolumn{1}{c}{ Componente da gestão ambiental } & Período & $\begin{array}{c}\text { Ano inicial } \\
(\%)\end{array}$ & $\begin{array}{c}\text { Ano final } \\
(\%)\end{array}$ & $\begin{array}{c}\text { Crescimento anual } \\
(\%)\end{array}$ \\
\hline Funcionários nos órgãos municipais (média) & $2002-2008$ & 7,4 & 13,6 & 13,96 \\
Gastos Públicos (conforme este estudo) & $2002-2011$ & 0,25 & 0,44 & 8,44 \\
\hline
\end{tabular}

Fonte: Neves (2013).

Elaboração dos autores.

Ainda no gráfico 2, percebe-se um crescimento mais acentuado entre os anos de 2005 e 2006, de modo que foi justamente neste período que os gastos ambientais passaram da ordem de $0,20 \%$ para a de $0,40 \%$. Tal fato, provavelmente, está relacionado à promoção, pelo governo estadual, da primeira estratégia de compartilhamento das açóes de licenciamento ambiental com os municípios, conforme Neves (2013, p. 28):

Mediante o atendimento a exigências definidas pelo Estado, Municípios foram autorizados a licenciar empreendimentos considerados de porte local, sendo celebrados acordos através de Convênios, mais tarde substituídos por Termos de Gestáo Compartilhada. O caráter local dos empreendimentos potencialmente impactantes foi definido caso a caso, através do indicador de porte. Os empreendimentos considerados de porte local deveriam ser, a partir de então, gerenciados pelos Municípios, entendendo-se como gerenciamento ambiental o conjunto de atividade de licenciamento, fiscalização e monitoramento.

As exigências estabelecidas para os Municípios pelo Estado do Pará foram as seguintes: promulgar lei de política ambiental, órgão municipal de defesa do meio ambiente (OMMA) estruturado e quadro técnico mínimo.

É possível também que tenha relação com a Lei no 11.284/2006 - Lei de Gestão de Florestas Públicas (Brasil, 2006) -, que instituiu o Serviço Florestal Brasileiro (SFB) em âmbito federal, impulsionando a gestão florestal como estratégica para o país. O governo do Pará criou, por meio da Lei Estadual nº 6.963/2007, uma instituição própria responsável pela gestão florestal no estado, o Instituto de Desenvolvimento Florestal do Estado do Pará (Ideflor). O crescimento das arrecadaçôes por concessóes florestais expedidas por esta instituição, no período de 2007 a 2009, provavelmente, contribuiu para o aumento dos gastos públicos ambientais municipais neste período (gráfico 2), uma vez que uma parcela destes recursos arrecadados vai para os municípios investirem em gestão ambiental (Ideflor, 2010). Outra tendência verificada foi a de decrescimento do coeficiente de variação dos gastos ambientais (gráfico 3), indicando que a proporção das despesas está se tornando mais homogênea entre os municípios. 


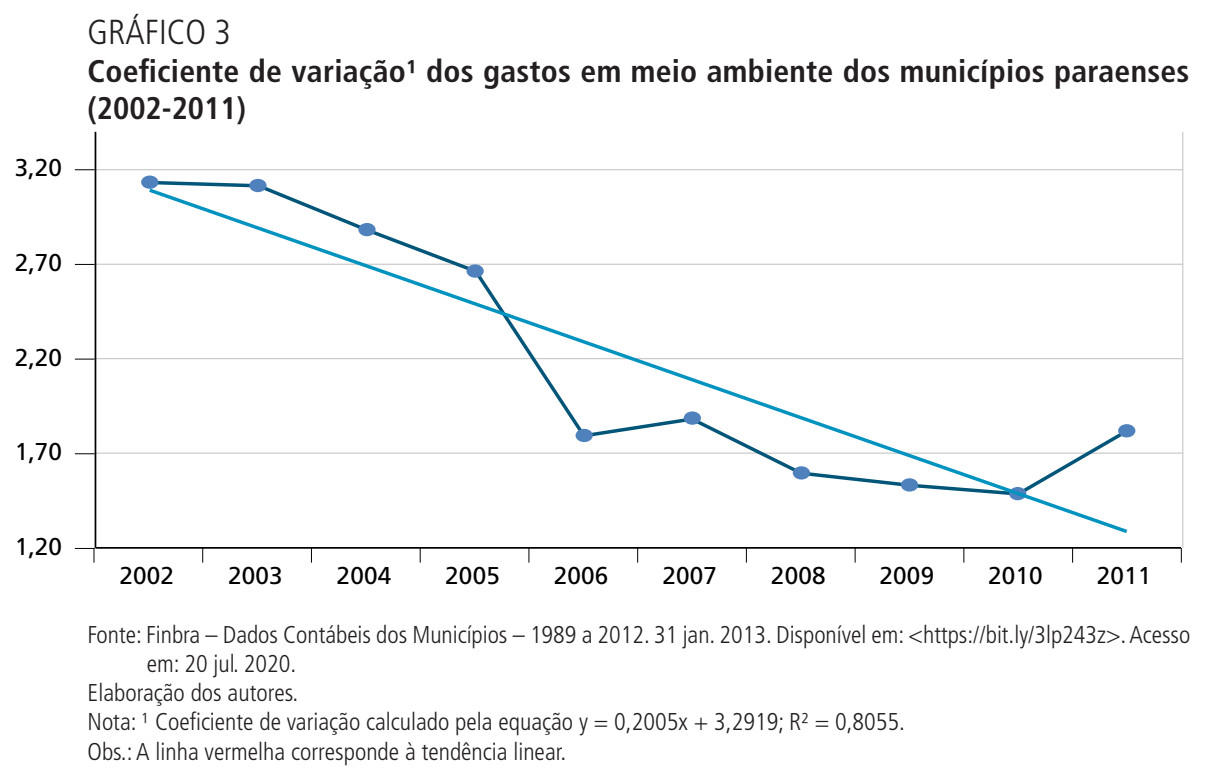

Dessa forma, deduz-se que o crescimento das despesas em gestão ambiental tem sido maior em municípios que antes gastavam menos nessa função orçamentária. De fato, alguns municípios paraenses conseguiram atingir um patamar relativamente bom de estrutura de gestáo ambiental já no início dos anos 2000 - é possível que, nestes municípios, os gastos ambientais tenham se tornado mais estáveis até o final da década, ao passo que cresceram em outros municípios.

\subsection{Empenho da gestão financeira ambiental municipal}

Em cerca de 83,2\% dos municípios paraenses, as médias das despesas em gestão ambiental foram abaixo de $0,57 \%$ das despesas totais. Por outro lado, $72 \%$ dos municípios apresentaram dados de despesas ambientais em mais de oito dos dez anos estudados e 60,8\% apresentaram tendência de crescimento dos gastos ambientais (gráfico 4). Considerando os critérios para medição do empenho da gestão financeira ambiental (quadro 2), percebe-se que a maior parte dos municípios obteve empenho bom (cerca de $42 \%$ ) ou ruim (cerca de $34,3 \%$ ), enquanto que os empenhos ótimo, regular e péssimo não passaram de $12 \%$ (gráfico 5).

É importante ressaltar, no entanto, que tal estimativa do empenho ambiental municipal não deve ser conclusiva. Existem dificuldades de estabelecimento de indicadores de efetividade das políticas ambientais, em função tanto das peculiaridades de cada região como do tempo necessário para que os projetos ambientais possam ter efeito positivo (Bell e Morse, 2008). Neves (2013) considera que as atividades ambientais desenvolvidas pelos municípios paraenses são majoritariamente de controle e licenciamento ambiental, de modo que gastos com preservação ainda são minoritários, o que pode comprometer a efetividade da gestáo ambiental municipal ao longo prazo. 
GRÁFICO 4

Municípios por critérios ${ }^{1}$

(Em \%)

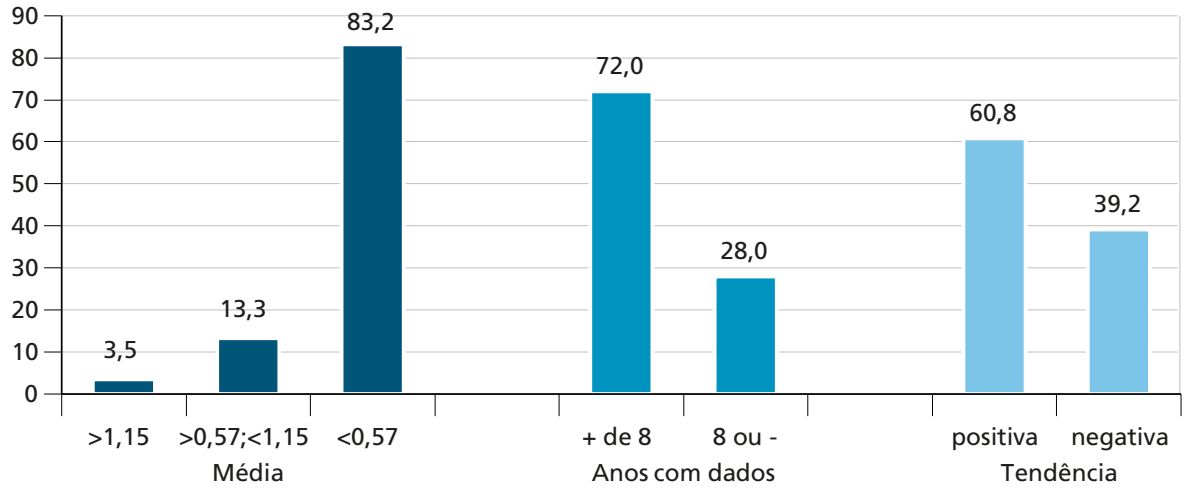

Fontes: Idesp (2011); e Finbra - Dados Contábeis dos Municípios - 1989 a 2012. 31 jan. 2013. Disponível em: <https://bit. ly/3lp243z>. Acesso em: 20 jul. 2020.

Elaboração dos autores.

Nota: ${ }^{1}$ i) média do percentual dos gastos públicos em meio ambiente em relação ao total dos gastos; ii) anos em que foram apresentados os gastos em meio ambiente; e iii) tendência de crescimento dos gastos em meio ambiente.

\section{GRÁFICO 5}

Municípios por empenho da gestão financeira ambiental e distinguidos por grupos (Em \%)

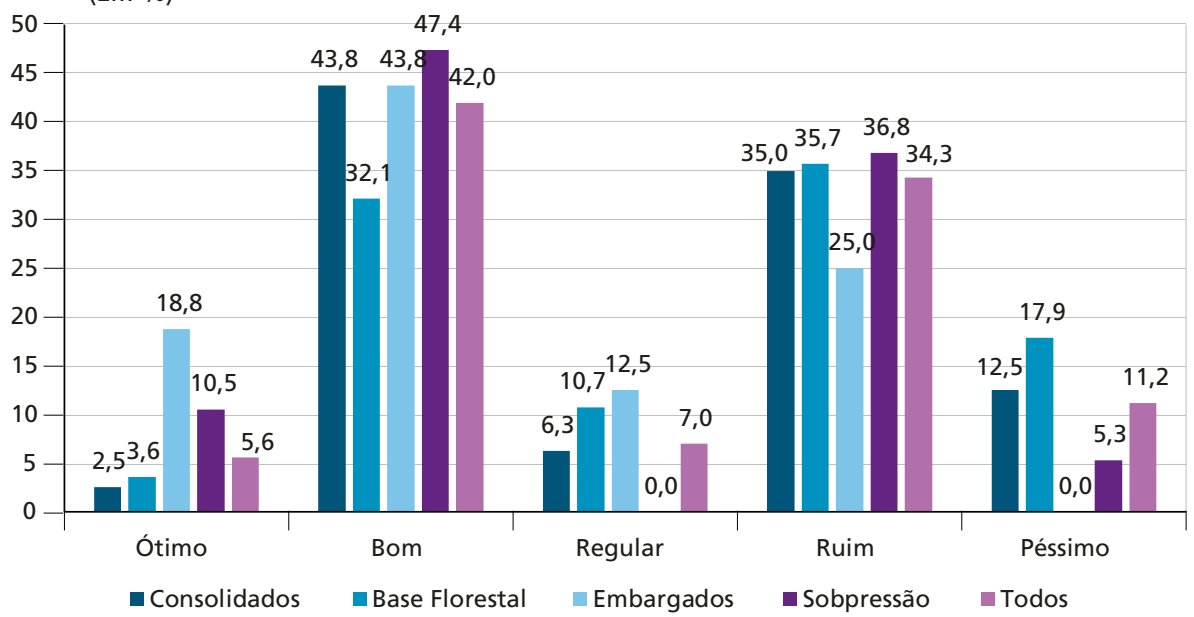

Fontes: Idesp (2011); e Finbra - Dados Contábeis dos Municípios - 1989 a 2012. 31 jan. 2013. Disponível em: <https://bit. ly/3lp243z>. Acesso em: 20 jul. 2020.

Elaboração dos autores.

Além disso, a efetividade depende também da gestão integrada das açóes voltadas para a preservação ambiental e o desenvolvimento sustentável, incluindo vários setores (Pereira, 2008; Dantas et al., 2014). As reduçóes das emissóes de gases de efeitos estufa (GEE), por exemplo, podem ser feitas por meio de outras funçôes orçamentárias (quadro 4), diferentes da gestão ambiental (IPCC, 2014). 


\section{QUADRO 4}

Exemplos de atividades que podem ser implementadas em outras funções orçamentárias e contribuir para uma melhor gestão ambiental no que diz respeito à redução das emissões de GEEs

\begin{tabular}{|l|l|}
\hline \multicolumn{1}{|c|}{$\begin{array}{c}\text { Setor/funçães } \\
\text { orçamentárias }\end{array}$} & \multicolumn{1}{c|}{ Atividades } \\
\hline Energia & $\begin{array}{l}\text { Descarbonização das fontes de energia elétrica. } \\
\text { Aumento da eficiência energética. } \\
\text { Adoção de matriz renovável menos poluente (energia eólica, solar, hidrelétrica etc.) ou de energia nuclear, } \\
\text { que não emitem GEE. }\end{array}$ \\
\begin{tabular}{|l} 
Transporte \\
Investimento no desenvolvimento ou adoção de veículos automotores mais econômicos ou mesmo movidos \\
Habitação \\
Replanejamento da infraestrutura urbana, priorizando os pedestres e os transportes coletivos.
\end{tabular} \\
\hline Indústria & $\begin{array}{l}\text { Estabelecimento de códigos de construção de habitações menos poluentes e que economizem o uso de } \\
\text { energia elétrica. } \\
\text { Uso de materiais de construção que demandem menos emissões de GEE. }\end{array}$ \\
\hline Agricultura & $\begin{array}{l}\text { Uso de materiais de maior eficiência energética, combinados com adoção de práticas de reciclagem e reúso. } \\
\text { Redução das emissões de hidrofluorcarbonetos pelo processo de otimização dos filtros industriais. } \\
\text { Implantação da gestão de resíduos sólidos. }\end{array}$ \\
\hline
\end{tabular}

Fonte: IPCC (2014)

Elaboração dos autores.

Por fim, mesmo considerando que as despesas ambientais, de fato, sejam as mais influentes, a determinação do nível ótimo de gastos púbicos, para que se saiba realmente o quanto se deve despender na função "gestão ambiental", é dificultada pelo fato de os municípios possuírem problemas ambientais e meios de enfrentá-los específicos (Guandalini, Borinelli e Godoy, 2013). A análise diferenciada de cada grupo estabelecido pelo PMV (Idesp, 2011) pode auxiliar na avaliação destas peculiaridades.

Nesse sentido, o gráfico 5 aponta para um aumento significativo do empenho: ótimo para os municípios embargados; e péssimo para os municípios de base florestal. Destaca-se ainda uma redução significativa do empenho: ótimo para os municípios consolidados e de base florestal; regular para os municípios pressionados; ruim e péssimo para os municípios embargados. Deve-se considerar, no entanto, que o número de municípios embargados e pressionados são relativamente pequenos (dezesseis e dezenove, respectivamente) em relação ao total de municípios do estado (143), o que diminui a confiabilidade da comparação para estes grupos (Gujarati e Porter, 2011).

\subsubsection{Municípios embargados}

Todos os municípios embargados apresentaram transparência com relação aos gastos ambientais em mais de oito dos dez anos estudados. Em relação à amostra como um todo (gráfico 4), a proporção de municípios que gastaram menos de 
$0,57 \%$ em gastos ambientais diminui de $83,2 \%$ para $68,8 \%$, em detrimento do aumento do número de municípios que gastaram entre $0,57 \%$ e $1,15 \%$, que passou de $13,3 \%$ para $31,3 \%$. Por outro lado, nenhum município gastou mais de $1,15 \%$, e não houve mudança significativa no percentual de municípios com tendência de crescimento positivo das despesas ambientais (gráfico 6).

GRÁFICO 6

Municípios embargados por critérios ${ }^{1}$

(Em \%)

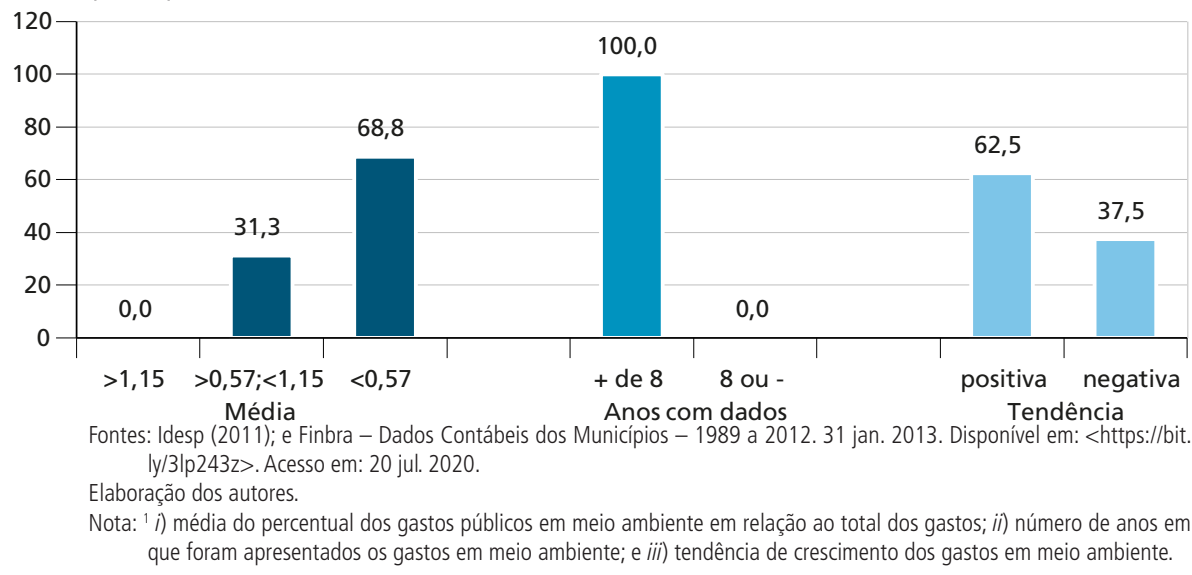

Entre os municípios embargados, três apresentaram estrutura ambiental completa: Altamira, Marabá e Moju (Idesp, 2011). Altamira teve uma média de $0,42 \%$ de gastos ambientais (em relação aos gastos totais), acima da média dos municípios do estado $(0,33 \%)$. O município apresentou dois anos com despesas zero (2002 e 2009) e um ano sem dados (2005), além de ter tido um percentual atípico (apenas 0,09\%) de gastos ambientais no ano de 2011. Considerando o período de 2003 a 2010, o crescimento dos gastos foi muito baixo, de apenas $0,18 \%$ a.a. Altamira apresentou o empenho bom, não confirmando a hipótese de pesquisa (quadro 5). 
QUADRO 5

Municípios que apresentaram estrutura completa de gestão ambiental, com indicadores da gestão financeira ambiental

\begin{tabular}{|c|c|c|c|c|c|c|}
\hline Classe & Município & $\begin{array}{l}\text { Média dos } \\
\text { gastos } \\
(\%)\end{array}$ & $\begin{array}{c}\text { Crescimento } \\
\text { dos gastos } \\
(\%)\end{array}$ & $\begin{array}{c}\text { Anos com } \\
\text { despesa zero }\end{array}$ & $\begin{array}{c}\text { Anos sem } \\
\text { dados }\end{array}$ & $\begin{array}{c}\text { Empenho da } \\
\text { gestão financeira } \\
\text { ambiental }\end{array}$ \\
\hline \multirow{3}{*}{ Embargados } & Altamira & 0,42 & $0,18^{1}$ & 2002 e 2009 & 2005 & Bom \\
\hline & Marabá & 1,05 & - & - & - & Ótimo \\
\hline & Moju & 0,11 & $17^{2}$ & De 2002 a 2007 & - & Péssimo \\
\hline \multirow{2}{*}{ Pressionados } & Tucuruí & 0,10 & 202 & - & 2008 & Bom \\
\hline & Uruará & 0,39 & 38 & 2004 e 2005 & 2007 e 2008 & Ruim \\
\hline \multirow{5}{*}{ Consolidados } & Eldorado dos Carajás & 0,18 & - & $\begin{array}{c}2002,2003 \mathrm{e} \\
2005\end{array}$ & 2004 & Ruim \\
\hline & Floresta do Araguaia & 0,49 & -13 & $\begin{array}{l}2005,2009 \\
2010 \text { e } 2011\end{array}$ & - & Ruim \\
\hline & Irituia & 0,20 & - & $\begin{array}{l}2002,2003 \\
2005 \text { e } 2007\end{array}$ & $\begin{array}{l}2004,2008 \\
2010 \text { e } 2011\end{array}$ & Péssimo \\
\hline & Ourilândia do Norte & 0,18 & 30 & De 2002 a 2006 & - & Bom \\
\hline & Paragominas & 1,54 & 472 & 2003 & - & Ótimo \\
\hline $\begin{array}{l}\text { Base } \\
\text { Florestal }\end{array}$ & Óbidos & 0,09 & - & $\begin{array}{l}\text { 2004; de } 2006 \\
\quad \text { a } 2009\end{array}$ & 2005 e 2011 & Ruim \\
\hline
\end{tabular}

Fontes: Baseado em Idesp (2011) e Finbra - Dados Contábeis dos Municípios - 1989 a 2012. 31 jan. 2013. Disponível em: $<$ https://bit.ly/3lp243z>. Acesso em: 20 jul. 2020.

Notas: ${ }^{1}$ Considerado para o período de 2003 a 2010.

${ }^{2}$ Considerado para 2009 a 2011.

Marabá apresentou uma média de 1,05\% de gastos ambientais em relação ao total, cerca de três vezes maior do que a média dos municípios do estado. O percentual dos gastos ambientais em Marabá cresceu cerca de $19 \%$ a.a., passando de $0,54 \%$, em 2002, para 1,56\%, em 2011. Além disso, o município também não apresentou nenhum ano sem despesas ambientais, tendo apresentado, desta forma, o empenho ótimo, confirmando a hipótese de pesquisa. Já Moju apresentou uma média de gastos ambientais de $0,11 \%$ do total. As despesas ambientais foram atípicas (apenas 0,003\% do total) no ano de 2008 e zero no período de 2002 a 2007. Desta forma, o empenho de Moju foi considerado péssimo, contrariando a hipótese de pesquisa (quadro 5).

\subsubsection{Municípios pressionados}

Entre os municípios pressionados, destaca-se, em relação à amostra como um todo (gráfico 4), o aumento do percentual de municípios com tendência de crescimento positivo, que passou de $60,8 \%$ para $68,4 \%$. Os demais fatores não alteraram significativamente (gráfico 7). Dois municípios pressionados apresentaram estrutura ambiental completa: Tucuruí e Uruará (Idesp, 2011). 
GRÁFICO 7

Municípios pressionados por critérios ${ }^{1}$

(Em \%)

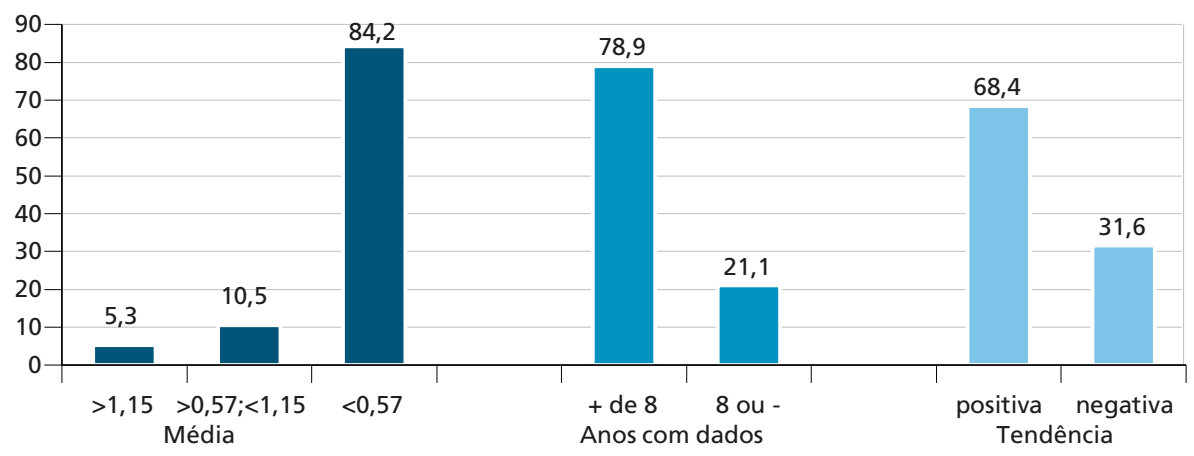

Fontes: Idesp (2011); e Finbra - Dados Contábeis dos Municípios - 1989 a 2012. 31 jan. 2013. Disponível em: <https://bit. ly/3lp243z>. Acesso em: 20 jul. 2020.

Elaboração dos autores.

Nota: ${ }^{1}$ i) média do percentual dos gastos públicos em meio ambiente em relação ao total dos gastos; ii) anos em que foram apresentados os gastos em meio ambiente; e iii) tendência de crescimento dos gastos em meio ambiente.

Tucuruí teve uma média de gastos ambientais de $0,1 \%$ dos gastos totais, cerca de três vezes menos do que a média dos municípios do estado (0,33\%). Apesar disso, o crescimento dos gastos foi alto ( $202 \%$ a.a.), em virtude do percentual baixo em 2002, de 0,0008\%, passando para 0,017\% em 2011. Tucuruí não apresentou dados para o ano de 2008, tendo, mesmo assim, um desempenho bom, mas contrariando a hipótese de pesquisa. Já Uruará teve uma média de gastos ambientais de $0,39 \%$ do total (ligeiramente acima da média dos municípios paraenses), com crescimento de $38 \%$ a.a., indo de 0,08\%, em 2002, para 0,39\%, em 2011. O município apresentou, no entanto, dois anos com despesas zero (2004 e 2005) e outros dois sem dados (2007 e 2008), tendo, assim, um empenho ruim, também contrariando a hipótese de pesquisa (quadro 5).

\subsubsection{Municípios consolidados}

Entre os munícipios consolidados, não há uma mudança significativa em relação à amostra como um todo (gráficos 4 e 8), o que pode estar relacionado ao fato de o número de municípios neste grupo ser grande (oitenta municípios, que correspondem a cerca de $60 \%$ do total). Foram cinco municípios com estrutura ambiental completa: Eldorado dos Carajás, Floresta do Araguaia, Irituia, Ourilândia do Norte e Paragominas. Eldorado dos Carajás teve um gasto médio ambiental de $0,18 \%$ das despesas totais, com despesas zero nos anos de 2002, 2003 e 2005; e sem dados em 2004 - obteve, assim, um empenho ruim da gestão ambiental, contrariando a hipótese de pesquisa. 
GRÁFICO 8

Municípios consolidados por critérios ${ }^{1}$

(Em \%)

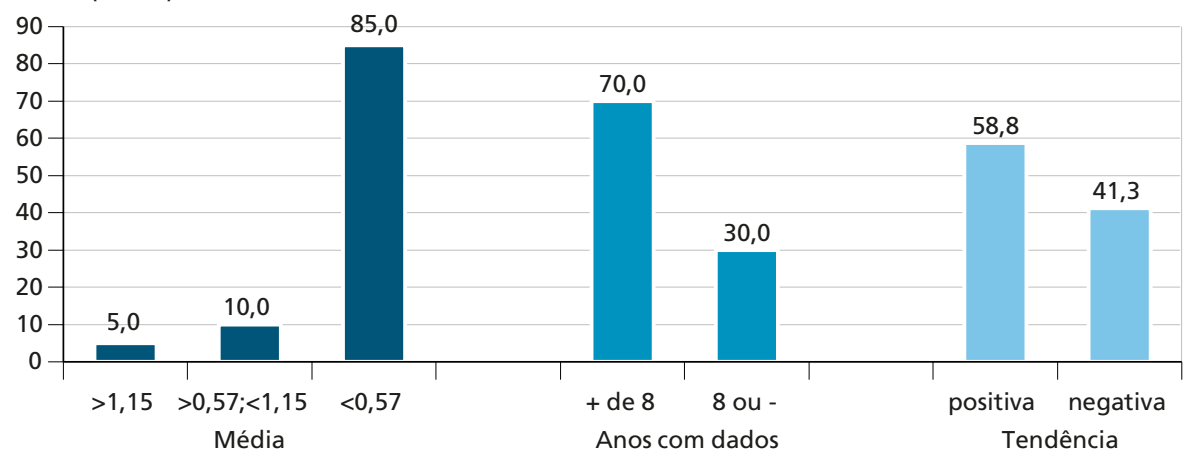

Fontes: Idesp (2011); e Finbra - Dados Contábeis dos Municípios - 1989 a 2012. 31 jan. 2013. Disponível em: <https://bit. ly/3|p243z>. Acesso em: 20 jul. 2020.

Elaboração dos autores.

Nota: ${ }^{1}$ i) média do percentual dos gastos públicos em meio ambiente em relação ao total dos gastos; ii) anos em que foram apresentados os gastos em meio ambiente; e iii) tendência de crescimento dos gastos em meio ambiente.

Floresta do Araguaia teve uma média de gastos ambientais de 0,49\% do total, acima da média dos municípios paraenses, apresentando, no entanto, uma tendência de queda de $13 \%$ a.a.: o percentual passou de $2,15 \%$, em 2002 , para $0,22 \%$, em 2008. O município também apresentou despesas zero para os anos de 2005, 2009, 2010 e 2010, tendo obtido o empenho ruim, contrariando a hipótese de pesquisa. Já Ourilândia do Norte teve uma média de $0,18 \%$ de gastos ambientais em relação às despesas totais, com tendência de crescimento de $30 \%$ a.a., passando de $0,18 \%$, em 2007, para 0,46\%, em 2011 - em contrapartida, o município teve despesas zero nos anos anteriores, alcançando, assim, o empenho bom da gestáo ambiental, mas também não confirmando a hipótese de pesquisa (quadro 5).

Entre os municípios consolidados com capacidade de gestão completa, Irituia foi o que apresentou o pior empenho da gestáo ambiental (péssimo, contrariando a hipótese de pesquisa), com uma média de $0,20 \%$ de gastos ambientais em relação ao total, quatro anos com despesas zero $(2002,2003,2005$ e 2007) e outros quatro sem dados (2004, 2008, 2010 e 2011). Paragominas, por outro lado, obteve o empenho ótimo, e confirmou a hipótese de pesquisa, com uma média de gastos de $1,54 \%$ ambiental em relaçáo ao total, cerca de cinco vezes maior do que a dos municípios paraenses; uma tendência de crescimento de $472 \%$ a.a., passando de 0,04\%, em 2002, para 1,92\%, em 2011, tendo despesas zero apenas no ano de 2003 (quadro 5). 


\subsubsection{Municípios de base florestal}

Entre os municípios de base florestal, nenhum gastou mais de 1,15\% em meio ambiente em relação ao total de gastos. Além disso, destaca-se, em relação à amostra como um todo (gráfico 4), a queda na proporção de municípios com boa transparência (com dados para mais de oito anos dos dez estudados), que passou de $72 \%$ para $57,1 \%$ (gráfico 9 ).

\section{GRÁFICO 9}

Municípios de base florestal por critérios ${ }^{1}$

(Em \%)

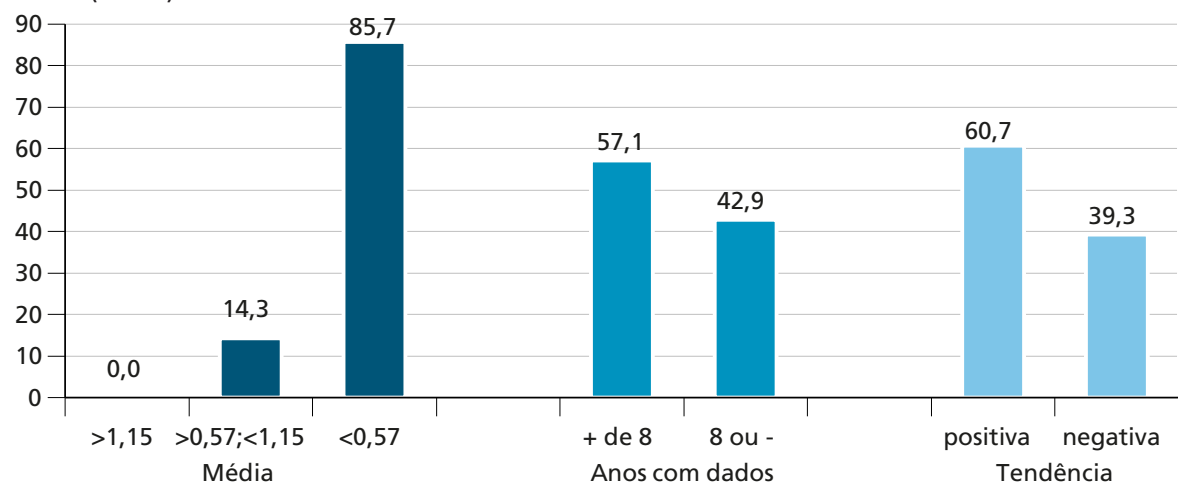

Fontes: Idesp (2011); e Finbra - Dados Contábeis dos Municípios - 1989 a 2012. 31 jan. 2013. Disponível em: <https://bit. ly/3lp243z>. Acesso em: 20 jul. 2020.

Elaboração dos autores.

Nota: ${ }^{1}$ i) média do percentual dos gastos públicos em meio ambiente em relação ao total dos gastos; ii) anos em que foram apresentados os gastos em meio ambiente; e iii) tendência de crescimento dos gastos em meio ambiente.

Apenas um município de base florestal possuía estrutura completa, Óbidos, o que não se refletiu, no entanto, no seu empenho da financeira ambiental (ruim). O município teve uma média de gastos ambientais de apenas 0,09\% do total de gastos, com despesas zero em 2004 e no período de 2006 a 2009; e sem dados em 2005 e 2011 (quadro 5).

\section{CONSIDERAÇÕES FINAIS}

O trabalho realizado constatou que a falta de transparência, no que tange aos gastos realizados, ainda é um problema grave para a gestão ambiental pública municipal no estado do Pará. Durante o período analisado (2002-2011), em média, 17,5\% dos municípios não apresentaram a função "gestão ambiental" em seu balanço orçamentário. Este percentual cresceu nos anos eleitorais (sobretudo em 2008, quando atingiu 32\%), indicando a provável influência política e a falta de interesse na realização do balanço orçamentário de governos anteriores. 
Os municípios paraenses apresentaram um percentual de despesas ambientais de $0,33 \%$ do total dos gastos públicos, um valor muito baixo se comparado com a média municipal brasileira $(0,81 \%)$ ou mesmo com a realidade de outros estados e municípios. Enquanto no Pará os governos municipais gastam proporcionalmente menos com gestáo ambiental do que o governo estadual, no Brasil ocorre o inverso: são os municípios que gastam mais em meio ambiente. Desta forma, pode-se inferir que, no contexto paraense, a transferência de recursos para gestão ambiental ainda está aquém da realidade brasileira.

Apesar disso, verificou-se a tendência de crescimento de $8,44 \%$ a.a. do percentual dos gastos ambientais, principalmente nos municípios que gastavam menos. Essa taxa de crescimento, no entanto, é baixa em comparação com outros componentes institucionais, como o percentual de municípios com conselhos e fundos ambientais ou o número de profissionais dos órgáos municipais de meio ambiente, o que indica que, no geral, náo houve alinhamento do crescimento dos percentuais de gastos em meio ambiente com o processo de descentralização e aumento das atribuiçóes ambientais para os municípios paraenses.

Além da tendência positiva de crescimento dos gastos ambientais, a maioria dos municípios paraenses apresentou despesas ambientais abaixo de $0,57 \%$ das despesas totais e dados de despesas para mais de oito dos dez anos estudados. Tais características gerais foram constatadas também para o grupo de municípios que possuem cobertura florestal original de aproximadamente $30 \%$ de seu território (consolidados).

Já para os demais grupos, verificou-se que a gestão financeira ambiental e a sua transparência foram justamente melhores para os municípios que mais desmataram (embargados) e piores para os municípios que possuem grande cobertura florestal original (base florestal). É provável que, nestes últimos, tenha ocorrido corte orçamentário na área de meio ambiente, com a concretização de riscos fiscais. Os municípios embargados tiveram as despesas maiores, provavelmente, em virtude de atividades de recuperação de danos ambientais. É possível que a formalização destes municípios como pertencentes à "lista dos que mais desmatam" tenha exercido uma pressão e contribuído para uma maior constância dos gastos, justificando a boa transparência.

No grupo de municípios sob influência de grandes projetos (pressionados), verificou-se o aumento do percentual de municípios com tendência de crescimento positivo dos gastos ambientais. É possível que tais projetos (de mineração, hidrelétricas etc.) corroborem para o aumento das despesas ambientais, mais associadas às atividades de conservação ou ao uso sustentável dos recursos naturais.

Por fim, a hipótese de pesquisa levantada, de que o empenho da gestão financeira ambiental foi ótimo nos municípios que apresentavam estrutura de 
gestão ambiental completa foi confirmada apenas para dois, Marabá (embargado) e Paragominas (consolidado), de onze municípios. Entre os municípios que não confirmaram a hipótese de pesquisa, destaca-se o empenho péssimo para Irituia (consolidado) e ruim para Uruará (pressionado), Eldorado dos Carajás e Floresta do Araguaia (consolidados) e Óbidos (base florestal).

Dessa forma, conclui-se que as despesas públicas ambientais feitas pelos municípios paraenses no período de 2002 a 2011 foram insuficientes e possuíram baixa transparência, ao passo que o crescimento verificado para estes gastos não acompanhou o aumento das atribuiçóes institucionais, mesmo nos municípios com capacidade de gestáo ambiental completa. Além disso, o crescimento dos gastos ambientais dos municípios paraenses foi induzido não por uma gestão preventiva, mas sim corretiva (uma vez que ocorreu principalmente nos municípios embargados), o que pode não ter sido a forma mais efetiva de se implementar a gestão ambiental municipal.

\section{REFERÊNCIAS}

BECKER, H. Segredos e truques da pesquisa. Rio de Janeiro: Zahar, 2007.

BELL, S.; MORSE, S. Sustainability indicators: measuring the immeasurable? 2. ed. London: Earthscan, 2008.

BELTRÃO, A. Direito ambiental. 2. ed. Rio de Janeiro: Forense; São Paulo: Método, 2009.

BORINELLI, B. et al. Gastos públicos em meio ambiente no estado do Paraná: uma análise exploratória para o período 2002 a 2009. Revista de Políticas Públicas, São Luís, v. 15, n. 1, p. 99-108, 2011.

BRASIL. Lei Federal no 6.938, de 31 de agosto de 1981. Dispõe sobre a Política Nacional do Meio Ambiente, seus fins e mecanismos de formulação e aplicação, e dá outras providências. Diário Oficial da União, Brasília, p. 16509, 2 set. 1981.

. Constituição da República Federativa do Brasil de 1988. Brasília: Assembleia Nacional Constituinte, 1988.

. Lei Complementar no 101, de 4 de maio de 2000. Estabelece normas de finanças públicas voltadas para a responsabilidade na gestâo fiscal e dá outras providências. Diário Oficial da Uniáo, Brasília, n. 86, seção 1, p. 68-85, 5 maio 2000a.

. Lei Federal no 9.985, de 18 de julho de 2000. Regulamenta o art. 225, $\$$ 1ำ, incisos I, II, III e VII da Constituição Federal, institui o Sistema Nacional de Unidades de Conservação da Natureza e dá outras providências. Diário Oficial da Uniáo, Brasília, 19 jul. 2000b. 
. Lei Federal no 11.284, de 2 de março de 2006. Dispóe sobre a gestão de florestas públicas para a produção sustentável; institui, na estrutura do Ministério do Meio Ambiente, o Serviço Florestal Brasileiro - SFB; cria o Fundo Nacional de Desenvolvimento Florestal - FNDF; altera as Leis $n^{\text {os }} 10.683$, de 28 de maio de 2003, 5.868, de 12 de dezembro de 1972, 9.605, de 12 de fevereiro de 1998, 4.771, de 15 de setembro de 1965, 6.938, de 31 de agosto de 1981, e 6.015, de 31 de dezembro de 1973; e dá outras providências. Diário Oficial da Uniáo, 3 mar. 2006.

. Lei Complementar no 140, de 8 de dezembro de 2011. Fixa normas, nos termos dos incisos III, VI e VII do caput e do parágrafo único do art. 23 da Constituição Federal, para a cooperação entre a União, os Estados, o Distrito Federal e os Municípios nas ações administrativas decorrentes do exercício da competência comum relativas à proteção das paisagens naturais notáveis, à proteção do meio ambiente, ao combate à poluição em qualquer de suas formas e à preservação das florestas, da fauna e da flora; e altera a Lei no 6.938, de 31 de agosto de 1981. Diário Oficial da União, Brasília, 9 dez. 2011.

BUARQUE, S. Metodologia de planejamento do desenvolvimento local e municipal sustentável: projeto de cooperaçâo técnica Incra/IICA. Brasília: Incra; IICA, 1999. BUENO, W.; OLIANA, F.; BORINELLI, B. O estudo do gasto público em meio ambiente. Economia e Regiáo, Londrina, v. 1, n. 1, p. 118-133, jan./jul. 2013.

BURSZTYN, M. A.; BURSZTYN, M. Fundamentos de política e gestão ambiental: caminhos para a sustentabilidade. Rio de Janeiro: Garamond, 2012.

CARNEIRO, A.; MOURA, A.; GOUVEIA NETO, S. Análise da função de despesa gestão ambiental nos municípios de Rondônia. Revista de Estudos Contábeis, Londrina, v. 4, n. 7, p. 77-97, jul./dez. 2013.

COSTA, J.; FLEURY, M. O Programa "Municípios Verdes": estratégias de revalorização do espaço em municípios paraenses. Ambiente e Sociedade, v. 18, n. 2, p. 61-76, 2015.

COUTO, T.; FREY, M. Análise da evidenciação da sustentabilidade pela contabilidade aplicada ao setor público municipal. Revista de Contabilidade da UFBA, Salvador, v. 11, n. 2, p. 45-62, maio/ago. 2017.

DANTAS, M. et al. Análise dos gastos públicos com gestão ambiental no Brasil. Revista de Gestáo Social e Ambiental, São Paulo, v. 8, n. 3, p. 52-68, set./nov. 2014. ESTADO DO PARÁ. Programa Municípios Verdes. Quem somos. Governo do estado do Pará, [s.d.]. Disponível em: <https://bit.ly/32kLhaB>. Acesso em: 14 set. 2016. GUANDALINI, N.; BORINELLI, B.; GODOY, D. Gastos públicos ambientais nas capitais dos estados brasileiros: um estudo exploratório no período de 2002 a 2010. Ciências Jurídicas e Empresariais, Londrina, v. 14, n. 2, p. 207-216, set. 2013. 
GUJARATI, D.; PORTER, D. Econometria básica. 5. ed. Porto Alegre: McGrawHill Companies, 2011.

HENDRIKSEN, E.; BREDA, M. Teoria da contabilidade. 1. ed. São Paulo: Atlas, 1999.

IDEFLOR - INSTITUTO DE DESENVOLVIMENTO FLORESTAL DO ESTADO DO PARÁ. Relatório de atividades 2010. Belém: Ideflor, 2010.

IDESP - INSTITUTO DE DESENVOLVIMENTO ECONÔMICO, SOCIAL E AMBIENTAL DO PARÁ. Perfil da gestáo ambiental dos municípios paraenses: Programa Municípios Verdes. Belém: Idesp, 2011.

IPCC - INTERGOVERNMENTAL PANEL ON CLIMATE CHANGE. Technical summary: Working Group III contribution to the IPCC $5^{\text {th }}$ Assessment Report Climate Change 2014. Berlin: IPCC, 2014.

LOMBORG, B. L'ecologiste sceptique: le véritable état de la planète. Paris: Le Cherche Midi, 2004. 620 p.

MAURO, C. Questóes ambientais dos municípios. In: ROCHA, G. Gestáo ambiental: desafios e experiências municipais no estado do Pará. Belém: Numa/ UFPA; Edufra, 2007.

NEVES, E. Diagnóstico da gestão ambiental municipal no estado do Pará. Belém: PMV; Imazon; Clua, 2013.

NINA, A. S.; SZLAFSZTEIN, C. F. Efeitos de desastres naturais ao desempenho orçamentário do estado do Pará. Novos Cadernos NAEA, v. 17, n. 2, p. 265-285, dez. 2014.

PEREIRA, R. Orçamento público e os paradigmas do desenvolvimento sustentável. Revista do TCU, n. 112, p. 89-96, maio/ago. 2008.

PICOLI, R. Sistema Nacional de Unidades de Conservaçáo: gastos efetivos e gastos necessários para garantir a conservação dos benefícios sociais da biodiversidade brasileira. 2011. 134 f. Dissertação (Mestrado) - Universidade de Brasília, Brasília, 2011.

SCARDUA, F. Governabilidade e descentralizaçáo da gestáo ambiental no Brasil. 2003. 256 f. Tese (Doutorado) - Universidade de Brasília, Brasília, 2003.

SCARDUA, F.; BURSZTYN, M. Descentralização da política ambiental no Brasil. Sociedade e Estado, Brasília, v. 18, n. 1/2, p. 291-314, jan./dez. 2003.

SERPA, D. Dependência real ou aparente? Uma análise das finanças públicas municipais brasileiras. 2014. 80 f. Monografia (Graduação) - Universidade Federal do Paraná, Curitiba, 2014. 
SHIH, M.-C. Trust and transparency in network governance: the implication of Taiwan's anti-corruption activities. International Public Management Review, v. 11, n. 2, 2010. TRIDAPALLI, J. et al. Análise dos gastos ambientais no setor público brasileiro: características e propostas alternativas. In: ENCONTRO DA ASSOCIAÇÃO NACIONAL DE PÓS-GRADUAÇÃO E PESQUISA EM ADMINISTRAÇÃO, 34., 2010, Rio de Janeiro. Anais... Rio de Janeiro: Anpad, 2010.

YOUNG, C. Orçamento público para gestão ambiental: uma análise voltada para as áreas protegidas. In: SIMPÓSIO DE ÁREAS PROTEGIDAS, 3., 2005, Pelotas. Anais... Pelotas: SAP, 2005.

\section{BIBLIOGRAFIA COMPLEMENTAR}

BRASIL. Lei Federal no 7.804, de 18 de julho 1989. Altera a Lei no 6.938, de 31 de agosto de 1981, que dispóe sobre a Política Nacional do Meio Ambiente, seus fins e mecanismos de formulação e aplicação, a Lei no 7.735 , de 22 de fevereiro de 1989 , a Lei no 6.803 , de 2 de julho de 1980 , e dá outras providências. Diário Oficial da Uniáo, Brasília, p. 12026, 20 jul. 1989.

Resolução Conama no 237, de 19 de dezembro 1997. Dispôe sobre a revisão e complementação dos procedimentos e critérios utilizados para o licenciamento ambiental. Diário Oficial da Uniáo, Brasília, n. 247, seção 1, p. 30841-30843, 22 dez. 1997.

. Portaria no 42, de 14 de abril de 1999. Atualiza a discriminação da despesa por funçóes de que tratam o inciso I, do $₫ 1^{\circ}$, do art. $2^{2 \circ}$, e $\$ 2^{\circ}$, do art. $8^{\circ}$, ambos da Lei no 4.320, de 17 de março de 1964; estabelece conceitos de funçáo, subfunção, programa, projeto, atividade, operaçóes especiais e dá outras providências. Diário Oficial da Uniáo, Brasília, n. 71, p.1, seção 1, 15 abr. 1999.

ESTADO DO PARÁ. Lei Estadual no 6.963, de 16 de abril de 2007. Dispóe sobre a criação do Instituto de Desenvolvimento Florestal do Pará - Ideflor e do Fundo Estadual de Desenvolvimento Florestal - Fundeflor, e dá outras providências. Diário Oficial do Estado do Pará, n. 3906, 17 abr. 2007.

Data de submissão: 16/10/2017

Primeira decisão editorial em: 28/3/2018

Última versão recebida em: 3/1/2019

Aprovação final em: 7/1/2019 